\title{
Membangun Minat Siswa Sekolah Dasar Pemulung Dalam Mempelajari Bahasa Inggris Melalui Metode Fun Learning
}

\author{
Sulastri ', Ratnawati ${ }^{2}$, Fitri Radhiyani ${ }^{3}$ \\ 1, Universitas Muslim Indonesia \\ 2, Akademi Bahasa Asing UMI Makassar \\ 3. Universitas Negeri Makasar \\ ${ }^{1}$ sulastri.sulastri@umi.ac.id; ${ }^{2}$ ratnawati.ratnawati@umi.ac.id; 3 fitri.radhiyani@unm.ac.id
}

\begin{abstract}
Abstrak
Pembelajaran bahasa Inggris dengan menggunakan metode fun learning sangat efektif diimplementasikan bagi sekolah dasar, khususnya dalam pembelajaran bahasa Inggris karena siswa sekolah dasar sangat sulit melafalkan, menghafalkan kosa kata dan ungkapan bahasa Inggris yang sederhana. Lebih lanjut, diharapkan melalui metode fun learning para guru SD Pemulung dapat menerapkan pengajaran bahasa Inggris yang menyenangkan sesuai dengan kebutuhan anak. Selama pengajaran bahasa Inggris berlangsung, siswa diberi stimulasi dengan menggunakan metode fun learning sesuai dengan target yang ingin dicapai dari pengajaran ini membangun minat partisipasi aktif, keterlibatan, dan simpati siswa sekolah dasar dalam mempelajari bahasa Inggris dengan cara yang menyenangkan. pengabdian yang dilakukan benar-benar merupakan kegiatan yang berdampak positif dengan masyarakat khususnya warga pemulung yang berada di sekitar SD tersebut. Hasil kegiatan pengabdian menunjukkan perilaku kemampuan dan minat siswa meningkat dalam mempelajari bahasa Inggris sederhana dalam percakapan sehari-hari. Hal ini dapat dilihat melalui perubahan yang sangat signifikan yang ditemukan pada siswa yaitu siswa lebih antusias dan percaya diri dalam mengucapkan kata-kata sederhana dalam bahasa Inggris.
\end{abstract}

Kata Kunci: minat siswa, pembelajaran bahasa Inggris, fun learnng

\section{Pendahuluan}

Pembelajaran bahasa Inggris untuk anak-anak yang disebut English for Young Learners (TEYL) sedang berkembang di berbagai belahan dunia, terutama di negaranegara berkembang termasuk Indon esia. Kebijakan ini sudah berlangsung lama dan semakin perlu ditingkatkan pelaksanaannya. Hal ini terkait dengan upaya pemerintah untuk melatih siswa menjadi handal dan berkualitas yang mampu bersaing secara nasional maupun internasional.

Untuk mencapai target tersebut, bahasa Inggris telah menjadi mata pelajaran muatan lokal yang diajarkan di sekolah dasar. Pengenalan Bahasa Inggris sejak awal berlandaskan pada filosofi pengajaran, yaitu semakin dini seseorang diperkenalkan dengan bahasa target, maka semakin cepat dan baik. Anak akan menguasai dan memperoleh pengetahuan yang telah dipelajari (Harmer, 2007). 
Pada hakikatnya, pembelajaran anak-anak di sekolah dasar berbeda dengan orang dewasa yang masing-masing memiliki karakteristik yang berbeda. Anak-Anak umumnya ingin tahu, suka bermain, dan kurang konsentrasi. Dlam konteks ini, guru bahasa Inggris di sekolah dasar sebaiknya mengadopsi strategi, keterampilan atau metode pengajaran yang berbeda dari kelompok siswa lainnya.

Bagi siswa sekolah dasar, harapan dan impian mereka berada di tangan guru mereka. Tujuan dan aspirasi mereka dibentuk melalui interaksi dengan guru, maka hendaklah guru di sekolah dasar dapat mengemas pembelajaran dengan menarik, sehingga tidak akan menimbulkan kebosanan atau kurang perhatiannya siswa terhadap materi yang diajarkan. Oleh karena itu, tugas guru adalah membuat pembelajaran menjadi menarik dan menyenangkan (fun learning). Terkait dengan hal ini, Dinas Pendidikan dan Kebudayaan Kota Parepare dan lembaga Pembinaan dan Pengembangan Motivasi Sektor Informal (LP2MSI) Kota Parepare (2004) menyatakan bahwa materi untuk siswa sekolah dasar harus berfokus pada belajar sambil bermain yang mana pendekatan kompetensi yang digunakan: belajar untuk mengetahui, belajar untuk melakukan sesuatu secara mandiri dan belajar untuk hidup bersama.

Pada saat ini, siswa sekolah dasar diharapkan memiliki pemahaman bahasa Inggris yang lebih dalam, tetapi mereka menghadapi banyak kesulitan, terutama dalam pengucapan dan memori kosakata. Oleh karena itu, Pemanfaatan Audio visual Aids (AVA) dalam pembelajaran Bahasa Inggris sangat membantu dalam mengajarkan kosakata (Ratnawati \& Sulastri, 2021). Sehingga penggunaan metode fun learning untuk mengajar Bahasa Inggris dinilai sangat efektif di sekolah dasar.

Tujuan menggunakan fun learning ini diharapkan dapat membangun minat: partisipasi aktif dan keterlibatan Siswa SD belajar bahasa Inggris melalui pembelajaran yang menyenangkan. Selain itu, menurut Irawati Istadi (2005) bahwa secara umum ada 2 hal yang harus diperhatikan dalam menciptakan proses belajar yang menarik, yaitu: 1) kegiatan belajar harus memenuhi kebutuhan perkembangan anak seusianya. Kebutuhan perkembangan anak usia lima tahun berbeda dengan kebutuhan anak usia tujuh tahun. Setiap orang memiliki tahapan perkembangan sesuai dengan usianya. 2) pembelajaran yang menarik hanya dapat diciptakan melalui segala macam kreativitas, baik dalam pemilihan waktu, tempat, lingkungan, maupun penggunaan metode pembelajaran. Kreativitas dapat menghilangkan kebosanan dan membangkitkan semangat untuk keingintahuan, tantangan, dan semangat baru. Oleh karena itu, semakin beragam lingkungan belajar yang dapat dirancang, semakin besar potensi otak untuk merekam informasi dengan cara terbaik.

Yayasan An Nur Rappokalling menjadi lokasi pengabdian yang dipilih, mengingat yayasan ini mempunyai andil yang sangat besar untuk mendorong anak-anak pemulung dari tingkat SD hingga SMP agar memiliki life skill yang merupakan mitra yang berlokasi di kota Makassar sekitar 1,5 kilometer dari Perguruan Tinggi Universitas Muslim Indonesia sehingga memudahkan untuk melaksanakan pembelajaran bahasa Inggris. sedangkan informasi yang diperoleh dari wawancara informal dengan ketua yayasan adalah bahwa pemulung di sekolah dasar berasal dari keluarga miskin, serta pendidikan orang tua yang masih sangat minim sehingga guru direkomendasikan berpartisipasi dalam kegiatan pengabdian tersebut, tujuannya agar mereka dapat memperoleh 
pengetahuan terbaru di masa depan dan lebih kreatif dan inovatif dalam menciptakan kegiatan pembelajaran melalui metode pembelajaran yang menarik.

Menurut Endraswara (2009: 19) bahwa proses pembelajaran tidak selalu efektif dan efisien. Hasil proses pembelajaran tidak selalu yang terbaik karena serangkaian hambatan. Oleh karena itu, dengan menciptakan kondisi yang kondusif, pembelajaran akan lebih bermakna. Pembelajaran dapat melatih siswa untuk menguasai kreativitas bahasa Inggris.Untuk menciptakan kondisi tersebut, harus ada metode pembelajaran yang menarik yang dapat menyelenggarakan pembelajaran secara maksimal di dalam kelas.

Di antara semua temuan di atas, tim pelaksana kegiatan IBM tertarik untuk membantu guru meningkatkan kualitas bahasa Inggris melalui pembelajaran yang menyenangkan. Melalui pengajaran ini, guru dan siswa akan memahami berbagai ungkapan bahasa Inggris sederhana, sehingga siswa dapat berkomunikasi dengan baik. Memahami pentingnya mempersiapkan metode pembelajaran yang selaras dengan kondisi sekolah dasar dan kenyataan di lapangan.

\section{Metode Pelaksanaan}

\section{Tempat dan Waktu Pelaksanaan}

Ada dua tahap kegiatan pengabdian di lapangan, yaitu 1) Kegiatan utama pelaksanaan pengajaran bahasa Inggris yang disambut secara resmi oleh kepala Yayasan An Nur pada hari Senin, 17 Juli 2017 pukul 09.00 wita. Kegiatan tersebut berlangsung hingga 11 Agustus 2017. Tim pelaksana pengabdian yang terdiri dari guru berpartisipasi secara bersamasama siswa, dilaksanakan pada bulan Juli sampai Agustus yaitu seminggu tiga kali berturut-turut dan dua pertemuan untuk sekolah menengah pertama, Setiap pertemuan diiadakan selama 90 menit.

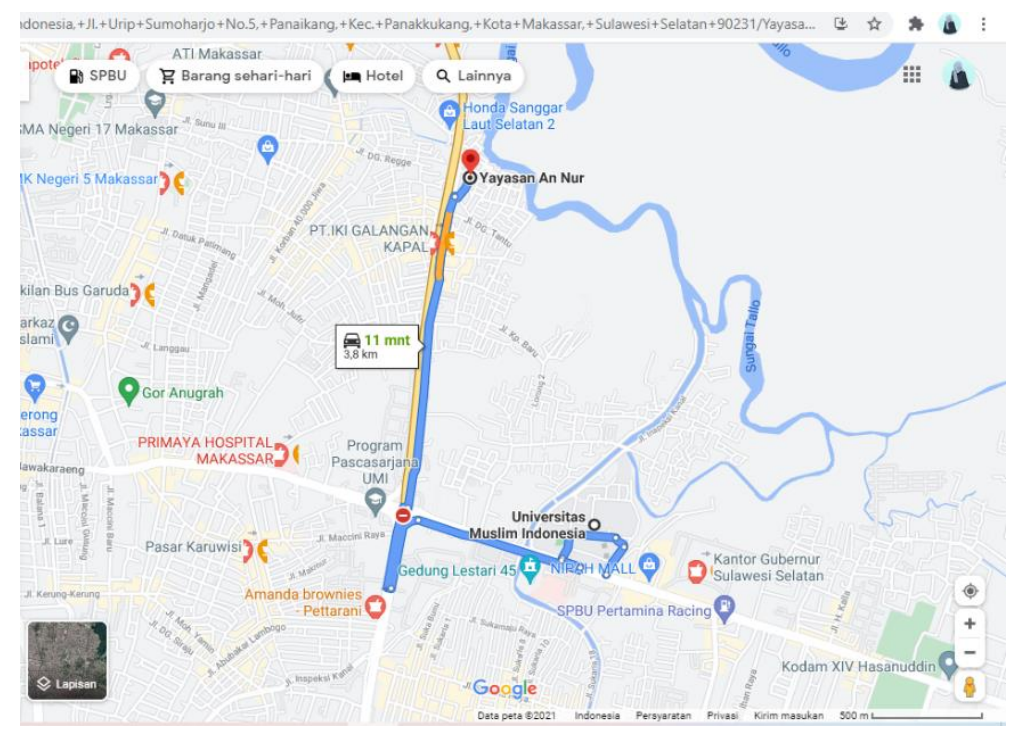

Gambar 1. Peta Lokasi Kegiatan Pengabdian

\section{Khalayak Sasaran / Mitra Kegiatan}

Yayasan An Nur Rappokalling Rappokalling merupakan yayasan yang membina sekolah pemulung mulai dari tingkat SD hingga SMP, sebagai mitra dalam pelaksanaan 
program Iptek bagi Masyarakat (IbM) merupakan mitra yang lokasinya tidak jauh dari pusat kota Makassar, sehingga pembelajaran Bahasa Inggris dapat dilaksanakan dengan lebih mudah.Namun, mengingat keterbatasan kapasitas sumber daya dan pemanfaatannya belum maksimal.

Yayasan An Nur Rappokalling ini memiliki 5 orang tenaga guru dan 3 orang tenaga pegawai dengan jumlah siswa (kurang lebih) 120 orang dan memiliki ruang 3 kelas. Sekolah dasar pemulung ini terletak di Jalan Rappokalling Utara samping tol Reformasi Kecamatan Tallo kota Makassar Provinsi Sulawesi Selatan. Tingkat pendidikan para guru, pegawai pada sekolah ini beberapa diantaranya bergelar sarjana, dan sekolah menengah atas.

Sedangkan sasaran utama dalam kegiatan adalah pembinaan siswa pemulung yang menyangkut proses belajar mengajar maupun terhadap pembinaan moral, semua kegiatan yang diprogramkan hendaknya menjadi motivasi bagi siswa pemulung untuk meningkatkan pengetahuan dimasa yang akan datang. Dalam kegiatan tersebut diikuti oleh sebanyak 20 siswa dan semua guru dilibatkan dalam proses pengajaran bahasa inggris tersebut.

\section{Metode Pengabdian}

Secara rinci metode-metode yang tim pelaksana pergunakan sebagai berikut.

1. Metode Ceramah

a. Pentingnya bahasa Inggris bagi siswa sekolah dasar;

b. Beberapa teknik dan metode pembelajaran yang dapat dikomparasikan dengan standar kompetensi pencapaian hasil belajar; dan

c. Contoh modul yang telah disusun oleh penulis.

2. Metode Tanya Jawab, digunakan untuk menjelaskan hal-hal yang kurang jelas atau dimengerti oleh para siswa yang mengikuti proses pembelajaran.

3. Metode kerja kelompok (diskusi), digunakan untuk membahas latihan-latihan pada modul yang tela $\mathrm{h}$ disiapkan oleh penulis.

4. Demonstrasi pembelajaran, metode ini dgunakan untuk memberikan contoh kepada siswa.

5. Pemberian Tugas, didiberikan untuk mengevaluasi apakah siswa mengerti terhadap materi yang telah diajarkan atau tidak, dan jika tidak berhasil maka perlu diberikan refleksi.

\section{Prosedur Kerja}

Secara rinci, tahapan-tahapan dari prosedur kerja kegiatan pembelajaran, adalah sebagai berikut:

\section{Tahap Persiapan}

a. Identifikasi kebutuhan. Dalam tahap ini dilakukan identifikasi untuk mendapatkan gambaran tentang kondisi sekolah serta kebutuhan pembelajaran bahasa Inggris.

b. Pengadaan media pembelajaran. 


\section{Pelaksanaan}

Pelaksanaan pengajaran bahasa Inggris dilaksanakan selama enam minggu dengan jumlah 20 siswa. Pengajaran ini ini melibatkan siswa dan beberapa guru pengajar sehingga dalam diharapkan nantinya guru pengampu dapat menerapkan metode ini dalam pembelajaran dikelas.

\section{Evaluasi dan Rencana Tindak Lanjut}

Indikator keberhasilan sebuah kegiatan pembelajaran tentu harus dilaksanakan evaluasi. Dalam hal ini, evaluasi meliputi evaluasi proses dan hasil yang dilakukan pada setiap tahap. Evaluasi ini meliputi semua tahap yaitu tahap persiapan sampai tahap pelaksanaan yang menyangkut keberhasilan siswa menyerap materi ajar, kesesuaian materi dengan keinginan dan kebutuhan siswa, kecocokan metode pengajaran terhadap tahap-tahap pemahaman sekaligus evaluasi oleh siswa untuk dosen. Dari pembahasan diatas, siswa tampak belajar dengan antusias, sungguh-sungguh menyimak dan memahami dengan mudah karena disajikan dengan sederhana. Selanjutnya, tahap evaluasi ini dilanjutkan dengan kegiatan penyusunan laporan.

\section{Tujuan Akhir atau Goal}

Tujuan akhir pengajaran bahasa Inggris adalah untuk melatih siswa SD agar memiliki minat dan kemampuan bahasa Inggris yang cukup melalui metode pembelajaran yang menarik, sehingga mereka dapat lebih mudah memahami beberapa kosakata bahasa Inggris ketika mereka melanjutkan sekolah ke tingkat yang lebih tinggi.

\section{Hasil dan Pembahasan}

Pengajaran bahasa Inggris dalam pengabdian ini membawa hasil yang signifikan siswa semakin antusias, termotivasi dan berpartisipasi aktif dalam setiap kegiatan yang dilaksanakan. Dan terkhusus bagi guru telah memberikan hasil yang memuaskan yaitu guru menjadi lebih terlatih dalam mengelola kelas melalui metode fun leaning yg diterapkan di dalam kelas.

Adapun bentuk kegiatannya dibagi menjadi dua yaitu (1) Pelaksanaan pengajaran tersebut dijadwalkan sesuai dengan pelajaran Mulok. Adapun realisasinya yaitu mulai dilaksanakan pada tanggal 17 Juli 2017 dengan materi pengajaran disesuaikan dengan topik dan kebutuhan siswa Pengajaran tersebut atas inisiatif dan permintaan Ketua Yayasan An Nur serta direspon oleh para guru SD pemulung tersebut dan (2) Kegiatan Penunjang lainnya berupa anjangsana ke tempat komunitas pemulung. Kegiatan penunjang lainnya yang dilakukan oleh tim pelaksana pengabdian yaitu anjangsana ke komunitas pemulung. Jadi kami mengsugesti diri kami sendiri dengan tidak hanya melakukan pengajaran dikelas, tetapi juga melakukan tindakan secara moril dengan melihat secara real dan langsung di lapangan. Acara kemanusiaan ini juga menyerahkan bingkisan berupa sembako dan pakaian bekas (layak pakai). Kami selaku tim pelaksana merasa senang karena dapat dilibatkan pada aktivitas seperti tersebut dengan memberikan sumbangsih kepada warga pemulung yang kehidupannya cukup memprihatinkan. 


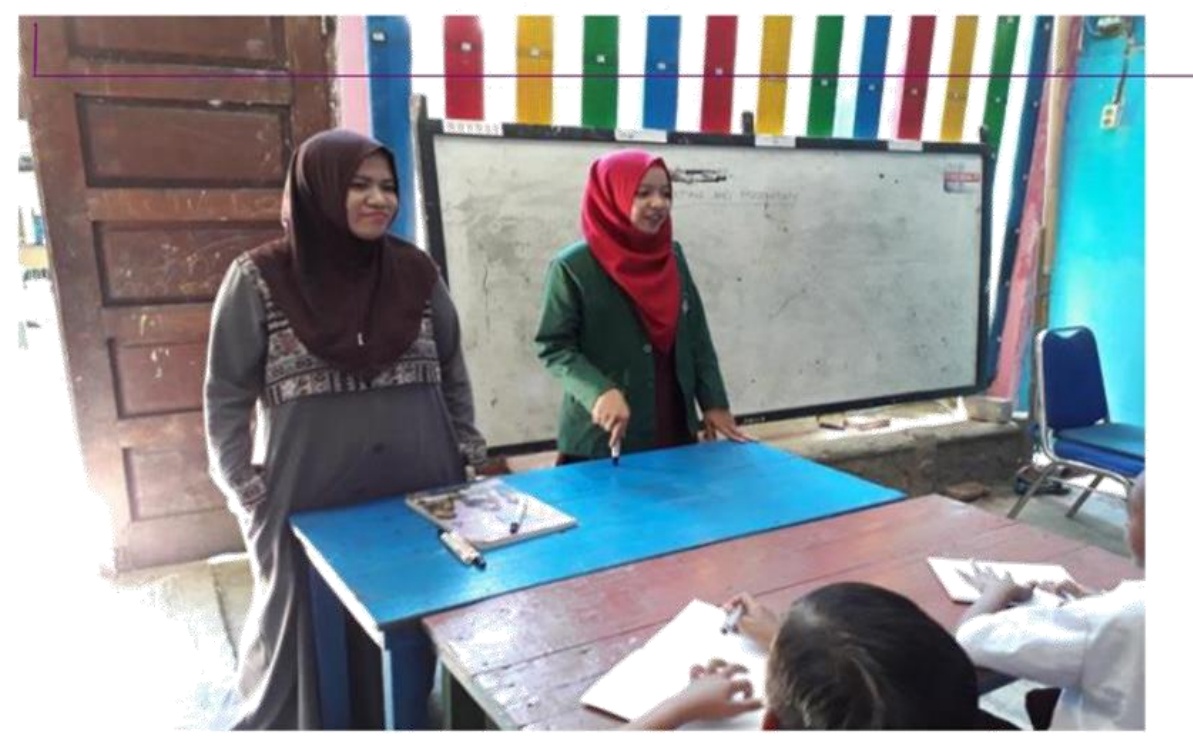

Gambar 2. Tim Pelaksana memperkenalkan diri dihadapan siswa

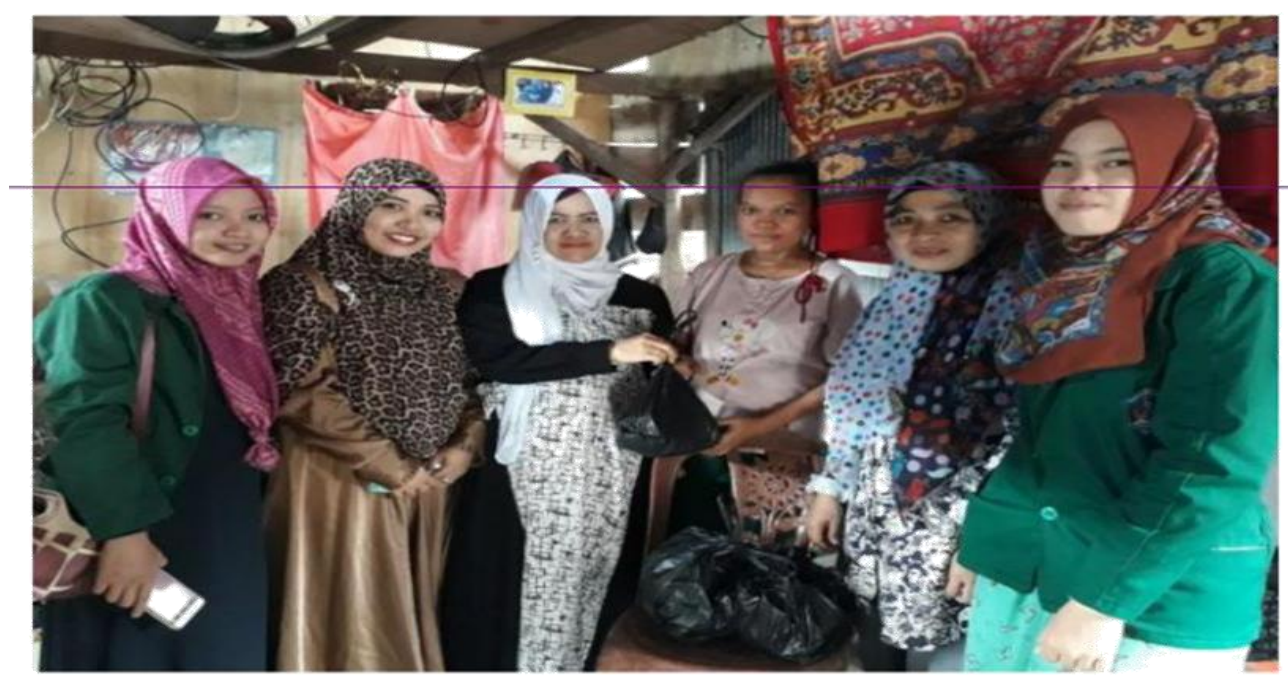

Gambar 3. Tim pengabdi melakukan angjangsana ke rumah warga

\section{Realisasi Pengajaran Bahasa Inggris Bagi Siswa Sekolah Dasar}

\section{Pertemuan Pertama}

Pada hari Senin tanggal 17 Juli 2017, kami tim pelaksana pengabdian memberikan materi Introduction: Greetings. Dalam menyampaikan materi kami menggunakan ice breaking yang berjudul coconut dance pada awal pertemuan untuk menciptakan keceriaan, semangat dan kesempatan untuk saling mengenal antar siswa dan kami selaku tim pelaksana pengabdian. Teknik role play kami gunakan dan media yang digunakan adalah papan tulis, spidol, dan modul. Dan di akhir pertemuan diberikan game terkait dengan materi yang disampaikan dan sanksinya bagi yang salah adalah memperkenalkan diri dalam bahasa Inggris.

Secara keseluruhan situasi belajar bahasa Inggris melalui introduction game baik dan lancar. Siswa merasa senang dan sangat berpartisipasi karena hal ini adalah pengalaman baru bagi mereka belajar bahasa Inggris melalui game. Namun, lagu juga disajikan pada 
pertemuan awal dengan judul "The More We Get Together". Mereka antusias karena ada kompetisi diantara mereka. Yang penting dalam hal ini siswa senang mengikuti pelajaran bahasa Inggris. Berdasarkan materi yang diberikan dari awal sampai akhir pertemuan ditemukan 10 siswa sangat mampu, 5 siswa sedang dan 5 siswa masih kurang.

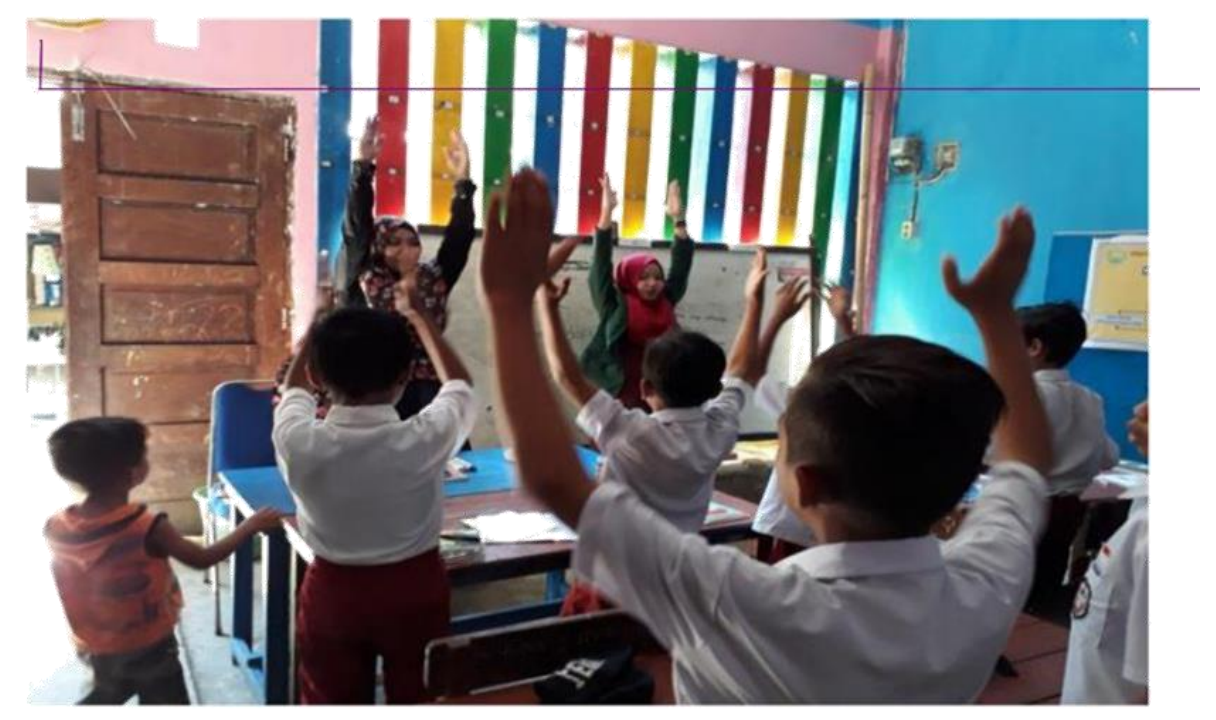

Gambar 4. Siswa melakukan warmin up bersama dengan tim pengabdi

\section{Pertemuan Kedua}

Pada hari Kamis tanggal 20 Juli 2017 memberikan materi : Days, Months and Years. Di awal pembelajaran diberikan game yang bertemakan Flash and Match dengan jumlah siswa sebanyak 15 orang. Kemudian pengajar menjelaskan cara memainkan game tersebut yaitu dengan mengajak siswa menghitung sama-sama (followed by pupils): one, two, three, four, five..........twenty four. Jadi kartunya juga berjumlah 24. Setiap kartu punya pasangan. Jadi kartu ada dua belas pasang. Setiap kartu ini membicarakan Day and Time. Nah silahkan dicari pasangan kartu tersebut, misalnya weekends pasangannya apa? Tentu saja Saturday and Sunday. Setelah dibagi menjadi empat kelompok, dimana setiap kelompok mempunyai juru bicara. Pengajar menunjuk kelompok 1 untuk menebak kartu dan juru bicaranya mengatakan: "we want number one and ten". pengajar akan membuka envelope number one and number ten jika kartunya match atau sesuai dengan pasangannya, maka group harus berteriak "Match It" maka group berhak diberikan card, sebaliknya, jika tidak sesuai, maka kesempatan kepada group berikutnya. Group yang paling banyak mengumpulkan matched cards itulah yang menjadi pemenang. Untuk menambah minat belajar siswa, maka di akhir pertemuan diberikan lagu yang berjudul Months in a year, semua siswa sangat enjoy lagu tersebut.

Menurut pembelajaran dan partisipasi dalam proses pembelajaran dapat ditarik kesimpulan bahwa 10 orang dengan kemampuan sangat baik, 3 orang dengan kemampuan sedang rata-rata dan 2 orang dengan kemampuan rendah.

\section{Pertemuan Ketiga}

Pada hari Senin tanggal 24 Juli 2017, kegiatan ini bertemakan Numbers dengan jumlah peserta 18 siswa, metode yang digunakan adalah tanya jawab dan media yang digunakan 
adalah papan tulis. Siswa mampu memahami materi dengan baik dan sebagai indikatornya yaitu mereka dapat mengerjakan soal latihan dengan mudah. Hal ini dibuktikan dengan mereka bekerja secara work in a group of four satu dari siswa menyebutkan number dan sebagian menjawab dan cross it out. Para siswa diminta untuk melengkapi huruf dari angka-angka yg hilang.

Untuk lebih meghidupkan susasana dalam kelas, maka tim pelaksana tak lupa memberikan game "how many", yaitu siswa diminta menebak berapa jumlah gula-gula yang ada di tangan pengajar, bagi siswa yang dapat menebak, maka akan diberikan gulagula tersebut. Alangkah senangnya mereka dengan diberikannya gula-gula tersebut. mereka berteriak dengan mengatakan "hore-hore, we have got it".

Lebih lanjut, dari awal pelajaran sampai akhir pelajaran, anak-anak kelihatan antusias dengan materi, game dan lagu yang disajikan, mereka sangat senang bahkan tim pelaksana sempat bingung pendapat siapa yang akan dia dengar, dan tak lupa tim pelaksana memberikan lagu yang liriknya satu ditambah satu sama dengan dua, dua ditambah dua sama dengan empat dan seterusnya tapi versi bahasa Inggris dan diikuti dengan gerakan dan mereka mendemonstrasikan dengan saling berdiri berhadapan. akhirnya semuanya berjalan lancar dan seru.

\section{Pertemuan Keempat}

Pada hari Kamis tanggal 27 Juli 2017, materi yang diberikan yaitu Fruits and Vegetables. Metode yang digunakan pada kesempatan ini yaitu ceramah dan tanya jawab. Kedua metode digunakan untuk menjelaskan fungsi dari masing-masing Fruits and Vegetables, namun meskipun demikian masih menggunakarn teknik role play karena kami memberikan materi dengan menggunkan media audio visual (video) yang ditayangkan.

Para siswa sangat fokus dan memperhatikan dengan saksama video tersebut dan cara melafalkan jenis fruits and vegetables. Kemudian mereka mempraktikkan percakapan sederhana seolah-olah seperti dalam video tersebut. Adapun bentuk percakapannya seperti Do you know what are in the video?, Which one do you like? Why do you like fruits?, where do you buy fruits?. Game yang diberikan dalam bentuk kartu dan siswa harus menebak buah dan sayuran mana yang tertera di kartu. Tim pelaksana dibagi menjadi dua kelompok untuk dalam memainkan game ini. Jika siswa dapat menebak nama buah dan sayuran dengan benar maka group mereka yang menjadi pemenang. Namun terlebih dahulu masing-masing group memberikan deskripsi singkat tentang buah dan sayuran yang akan ditebak.

\section{Pertemuan Kelima}

Pada hari Kamis tanggal 27 Juli 2015, pengajar memberikan materi dengan tema Noun. Metode yang digunakan ialah diskusi. Siswa mendiskusikan materi yang mereka tonton melalui audio visual (video) yang menayangkan penggunaan noun khusus untuk siswa sekolah dasar. Mereka sangat senang dengan tontonan yang diberikan karena untuk pertama kalinya mereka menonton dalam bahasa Inggris, jika ditanya bagaimana dengan tayangan video tadi? Mereka secara serentak menjawab bahwa menarik. Teknik yang digunakan yaitu "Dictation Game“. Keseruan juga melihat mereka bermain karena mereka harus melihat kartu yang ditempel di papan tulis kemudian mereka berlarian dan yaitu sebuah permainan yang mengggunakan alat indra pendengaran dan mata sebagai alat 
dalam permainan ini membisikkan kata-kata yang tercantum di kartu tersebut agar tidak kedengaran dengan kelompok yang lainnya. Pada kesempatan ini suasana kelas lebih tenang karena pengorganisasian kelas dilakukan oleh anggota tim pelaksana pengabdian. Dalam permainan ini semua siswa aktif karena punya andil untuk memainkan kartu.

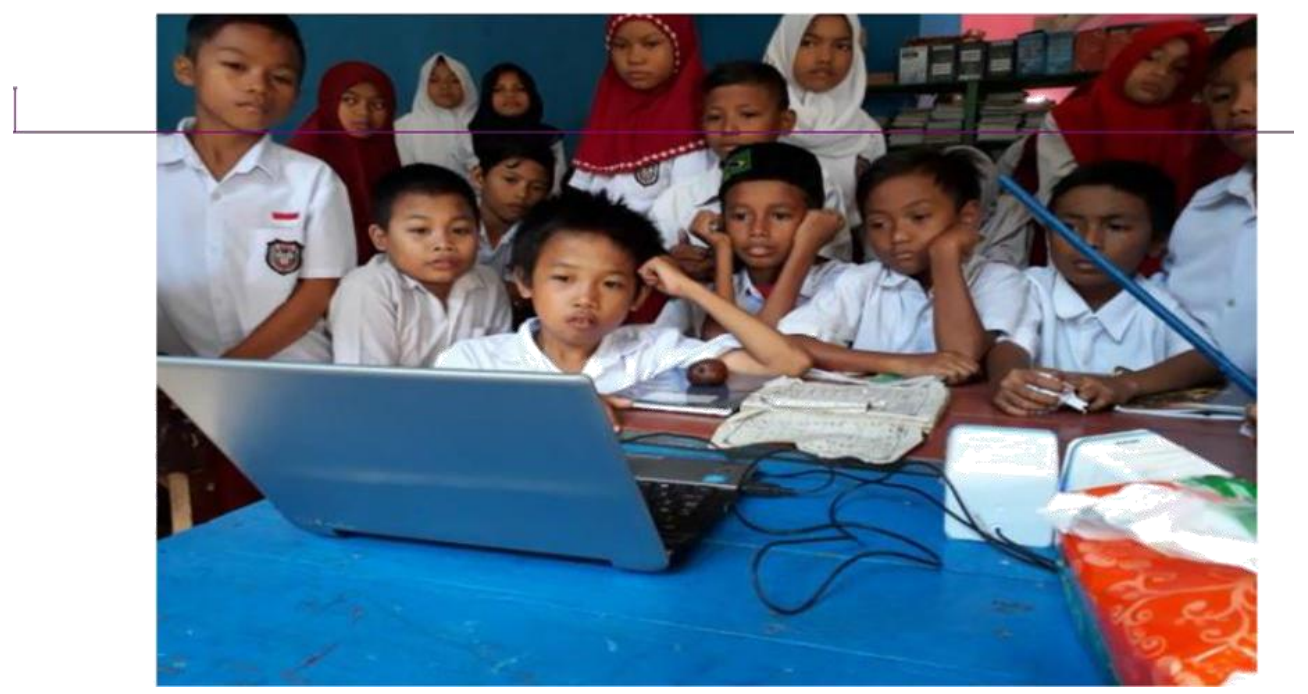

Gambar 5. Siswa menonton video

\section{Pertemuan Keenam}

Pada hari Kamis tanggal 27 Juli 2017 pengajaran bahasa Inggris dilakukan dengan materi "Parts of Body". Metode yang diterapkan dalam pertemuan ini adalah "Demonstran Method" melalui ice breaking pengucapan bagina-bagian tubuh yang benar secara langsung disebutkan dan diberikan contoh, dan siswa diharuskan melakukan apa yang dikatakan anggota tim pelaksana. yaitu hands up, palms together, elbow together, knee together, tiap satu aba-aba langsung bilang semua jugeja sambil goyang. Dan sebuah lagu yang juga diberikan, ini dilakukan untuk membuat suasana belajar yang lebih menarik dan menyenangkan. Pengajar memberikan game Identifying parts of body dengan menulis tiap kartu nama-nama anggota tubuh dan menginstruksikan kepada siswa untuk menempelkannya di bagian anggota tubuh mereka sambil bernyanyi. Jumlah siswqa ada 20 orang. Ada 17 siswa yang tergolong sangat baik karena dapat menyebutkan bagian-bagian tubuh dengan besar dan mengucapkannya dengan benar. Kemudian 5 orang diberi peringkat rata-rata karena mampu mnyebutkan bagian-bagian tubuh dengan benar, tetapi tidak dapat mengucapkannya dengan benar dan tepat, kategori terakhir adalah kategori rendah dengan hanya 3 siswa. dan dengan pengucapan yang benar. Kemudian ada 5 orang yang dikategorikan rata-rata, hal ini disebabkan mereka mampu menyebutkan bagian-bagian tubuh dengan tepat tetapi belum dapat mengucapkan dengan benar dan tepat. Dan kategori yang terakhir adalah kategori rendah yang hanya terdapat 3 orang siswa. 


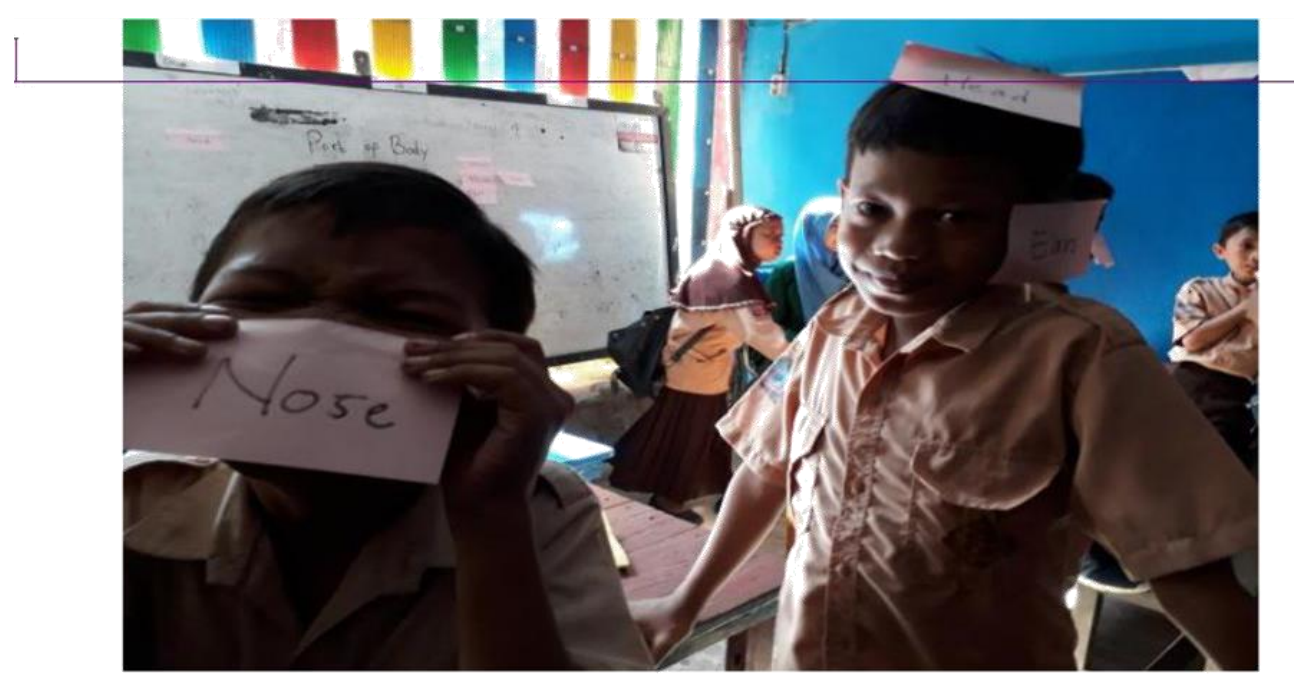

Gambar 6. Siswa sangat antusias diberikan instruksi pada parts of body game

\section{Pertemuan Ketujuh}

Padahari Jumat, 28 Juli 2017 pengajaran bahasa Inggris dilaksanakan dengan materi pokok "Great Commands". Sedangkan teknik yang digunakan adalah"Demonstrative", tujuannnya adalah untuk memberikan contoh kepada siswa untuk mendukung terlaksananya proses belajar secara kondusif maka media yang digunakan yaitu spidol dan papan tulis. Pada pertemuan kali ini game yang diberikan dinamakan pantomime, masing-masing siswa mencari pasangan mereka dan salah satunya menjadi pelaku. Pelaku mengambil sebuah kartu dan melakukan tindakan berdasarkan yang tercantum di kartu tersebut. Partnernya harus menebak tindakan atau gerakan yang dilakukan si pelaku tersebut. Suasana dalam kelas sangat meriah karena masing-masing siswa mencoba untuk menebak gerakan tersebut.

\section{Pertemuan Kedelapan}

Pada pertemuan kali ini, tepatnya tanggal 29 Juli 2017 hari Kamis merupakan pertemuan yang sangat berkesan menurut kami karena kami sengaja memilih topik Good Habit, hal ini disebabkan karena kami selaku tim pleaksana melihat kondisi real di lapangan mereka lebih banyak bergelut dengan sampah sehingga para siswa harus mendapat perlakuan khusus tentang PHBS.

Adapun jenis metode yang diimplemetasikan pada pertemuan kedelapan adalah ceramah, demonstrasi dan tanya jawab. Tim pelaksana pengabdian selain mengajar juga memberikan penyuluhan tentang pentingnya Good Habit dalam kehidupan sehari-hari. Selanjutnya siswa diberikan contoh bagaimana menjaga kesehatan dengan baik, contohnya mandi tiga kali sehari, menggosok gigi, dan sebagainya. Selanjutnya diberikan tugas dengan menjawab dialog yakni whaat good habit do you usually do? serta memlih kebiasaan yang baik pada gambar yang disediakan, lalu di akhir pertemuan diberikan game yang berjudul "The Healthy Song".

\section{Pertemuan Kesembilan}

Pengajaran bahasa Inggris yang kesembilan, dilaksanakan pada hari Selasa tanggal 01 Agustus 20 dengan materi Family Tree dan teknik yang digunakan yaitu pair work. Materi yang disampaikan diselingi dengan permainan yang berhubungan topik yang diberikan. 
Dihimbau setiap siswa untuk menyebutkan dengan benar istilah keluarga dan menggunakan kalimat sederhana untuk berbicara tentang keluarga. Selain itu, anggota tim melakukan tugas untuk menggambar silsilah keluarga dan menulis kalimat sederhana berdasarkan family tree (silsilah) dari anggota keluarga. Mereka dapat menguasai dan memahami istilah-istilah tersebut dan dapat membuat kalimat sederhana.yang berkaitan dengan family members dalam bahasa Inggris.

\section{Pertemuan Kesepuluh}

Pertemuan kesepuluh tanggal 03 Agustus 2017 dengan materi pertama Telling Time (menyatakan waktu). Metode yang digunakan yakni diskusi dan berfokus pada students centered Learning dengan game "Alphabetical Clock". Pengajar menunjukkan ke kelas alat peraga yang bertuliskan waktu dari kata-kata. Dia menulis kata train kemudian dia mengatakan bahwa huruf pertama $(\mathrm{t})$ menandakan jam dan huruf terakhir (n) menandakan menit. Ini berarti menunjukkan waktu twenty five to ten, siswa dibentuk menjadi 2 group dan pengajar menyeleksi waktu yang dikerjakan dan siswa yang memberikan jawaban yang benar itulah pemenangnya. Ada beberapa siswa yang tampak kebingungan, maka diberikan penjelasan ulang kepada siswa untuk lebih memahami game yang diberikan. Semua siswa tampak aktif mengikuti arahan dari si pengajar karena dimainkan dengan kelompok kecil. Semua berkesempatan memberikan masukan kepada spokesperson. Setiap siswa kelihatan menikmati permainan ini karena mereka mengambil bagian untuk bertanggungjawab menebak jam tersebut. Dan mereka berusaha melafalkan dan mengucapkan jam tersebut dengan benar.

\section{Pertemuan Kesebelas}

Pada Selasa tanggal 08 Agustus 2017 tim pelaksana menyajikan materi dengan topik Adjective (kata sifat) dengan jumlah siswa 25 orang. Topik game yang diberikan yaitu "adjective synonyms". Game ini dimainkan oleh empat pemain tapi karena kalian banyak maka kami membagi kalian menjadi enam kelompok. setiap group memainkan kartu. Kata yangg ada di kartu ini . Misalnya kata beautiful padanan katanya apa? padanannya ini yang berarti cantik. Tugas siswa mencari padanan kata dari setiap kartu . kemudian kartunya dikocok dulu kemudian dibagi habis kepada keempat pemain. Suasana kelas sangat ramai. Setiap anggota kelompok brinteraksi dengan kelompokyang lain dan beberapa siswa menyalahkan siswa yang lain karena penempatan kartu yang salah. Seluruh siswa dilatih mengucapkan dengan benar sambil bermain. Di akhir pertemuan, group tiga menjadi pemenangnya. Mereka sangat bahagia. Seluruh anggota kelompok berteriak "Yes! Yes! Yes!, We are the winner".

\section{Pertemuan Keduabelas}

Pada hari Kamis tanggal 10 Agustus 2017 tim pelaksana pengabdian melaksanakan pengajaran yang dihadiri oleh 20 siswa. Topik yang diberikan yakni demonstrative pronoun (kepemilikan) dengan menggunakan metode tanya jawab dan teknik yang digunakan yaitu role play dengan membuat percakapan singkat. Game yang dalam bentuk "puzzle" terkait dengan materi yang diberikan. Bentuk keterampilan yang diperoleh siswa adalah siswa dapat memahami penggunaan kata this/these dan that/those, dan penggunaan kata pria dan wanita yang benar dalam bahasa Inggris. Akhirnya harus diacungkan jempol karena mereka bisa menjawab teka-teki. benar. 


\section{Realisasi Pengajaran Bahasa Inggris Bagi Siswa SMP}

\section{Pertemuan Pertama}

Pada hari Jumat tanggal 11 Agustus 2017, materi yang diberikan yaitu Shopping (how much), siswa diinstruksikan untuk melakukan teknik role play karena kami memberikan materi dengan menggunkan media audio visual (video) yang ditayangkan.

Para siswa sangat fokus dan memperhatikan dengan saksama video tersebut dan cara melafalkan kosa kata yang relevan dengan barang dan harga. Kemudian mereka mempraktikkan percakapan sederhana seolah-olah seperti dalam video tersebut. Adapun bentuk percakapannya seperti How much do they cost? How much are they?. Game yang diberikan berupa kartu yang tercantum apa yang mereka harus beli dan berapa harga barang tersebut. Secara kebetulan sekolah dasar tersebut mempunyai warung, maka siswa melakukan role play secara langsung (authentic material). Tim pelaksana memberikan uang kepada siswa untuk dipakai belanja dan mereka melafalkan kosa kata yang relevan dengan shopping khususnya penggunaan how much.

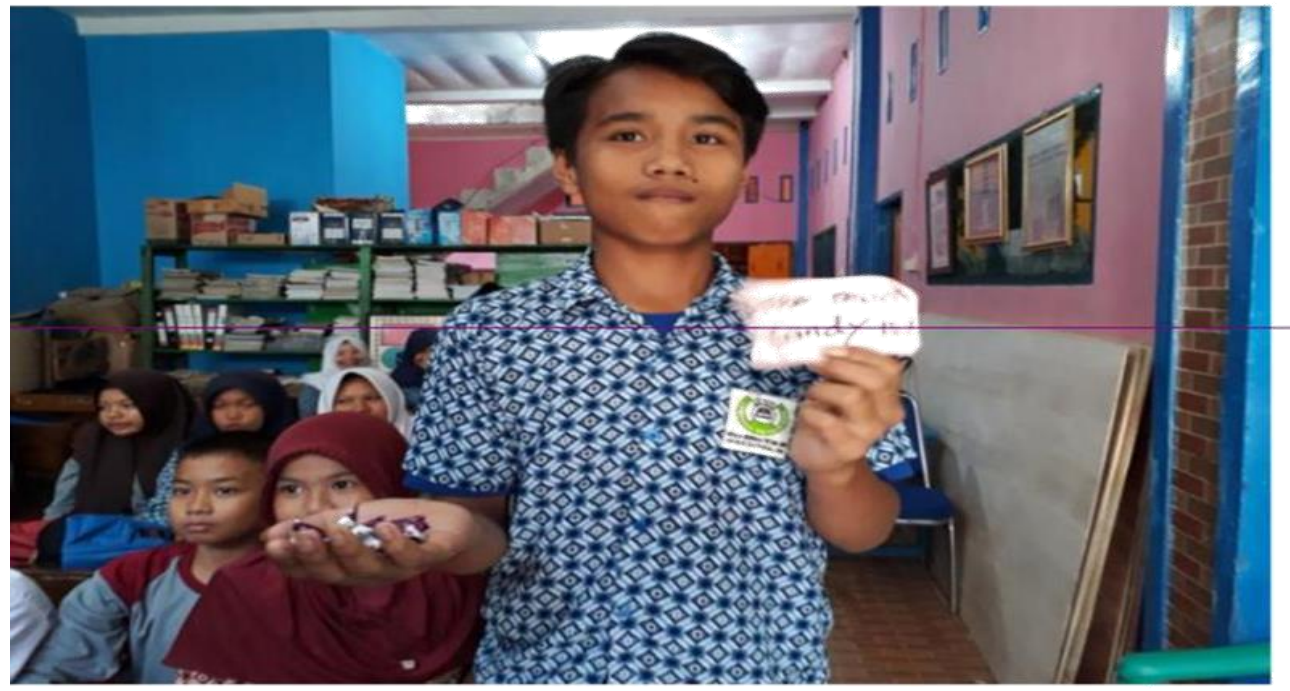

Gambar 7. Siswa melakukan role play

\section{Pertemuan Kedua}

Pertemuan kedua ini dilaksanakan di hari yang sama pada jam yang berbeda. Dengan materi verb. Metode yang digunakan yaitu metode tanya jawab. Untuk mengurangi kejenuhan siswa, maka diberikan lagi game yang lebih menantang karena siswa tidak hanya mencari pasangan kata tetapi juga membuat kalimat sederhana berdasarkan pasangan kata yang telah mereka tebak. Mereka dibatasi oleh waktu untuk menyebutkan kalimat. Dan tak lupa pula untuk menambah keceriaan dan keseruan dalam kelas, maka kami tim pelaksana memberikan hadiah kecil seadanya sebagai reward bagi siswa yang paling aktif selama proses pembelajaran.

\section{Kesimpulan}

Berdasarkan hasil kegiatan pengabdian kepada masyarakat tentang penerapan metode fun learning untuk menumbuhkan minat belajar bahasa Inggris siswa, dapat disimpulkan bahwa metode fun learning paling cocok untuk pembelajaran di kelas 
khusunya sekolah dasar karena model pembelajaran ini berisi kegiatan pembelajaran bahasa yang menarik. Hal ini tercermin dari antusias dan semangat siswa untuk mengikuti proses pembelajaran seolah-olah merasa tidak belajar melainkan belajar sambal bermain.

\section{Ucapan Terimakasih}

Kami selaku tim pelaksana pengabdian menyampaikan terima kasih yang tak terhingga kepada Lembaga Pengabdian kepada Masyarakat (LPkM) Universitas Muslim Indonesia yang telah mendanai dan memfasilitasi kegiatan pengabdian ini dan Yayasan An Nur Rappokalling sebagai mitra pengabdian atas sumbangsihnya terhadap kegiatan ini.

\section{Referensi}

Diknas dan LP2MSI Kota Pare Pare. (2004). Kurikulum Pembelajaran Bahasa Inggris Kelas $V$ dan VI Sekolah Dasar. ParePare: Dinas P dan K dengan LP2MSI

Endraswara, S. (2009). Metodologi Penelitian Sastra. Yogyakarta: Med Press.

Harmer, J. (2007). The Practice of English Language Teaching. Essex: Pearson Education Limited.

Irawati, I. (2005). "Funny Learning”. online http://simutmaniz.blogspot.com.

Ratnawati, R., \& Sulastri, S. (2021). Pemanfaatan Media Audio Visual Aids (AVA) dalam Pembelajaran Kosakata Bahasa Inggris di TPA Jannatul Firdaus. Madaniya, 2(2), 121-128. Retrieved from

https://madaniya.pustaka.my.id/journals/contents/article/view/40 